\title{
Immunohistochemical markers of prognosis in non-small cell lung cancer: a review and proposal for a multiphase approach to marker evaluation
}

\author{
C-Q Zhu, W Shih, C-H Ling, ${ }^{*}$ M-S Tsao
}

J Clin Pathol 2006;59:790-800. doi: 10.1136/jcp.2005.031351

Characteristics of the tumour that affect and predict the survival outcome of patients with cancer are prognostic markers for cancer. In non-small cell lung carcinoma (NSCLC), stage is the main determinant of prognosis and the basis for deciding options for treatment. Patients with earlystage tumour are treated by complete surgical resection, which is curative in $40-70 \%$ of patients. That there are other factors important in determining the biology of these tumours, especially genes that have a role in metastasis, is indicated. Such factors could potentially be used to further classify patients into groups according to substages that may be treated differently. During the past decade, a large number of proteins that are putatively important in carcinogenesis and cancer biology have been studied for their prognostic value in NSCLC, but none of them have been proved to be sufficiently useful in clinical diagnosis. Several markers (epidermal growth factor receptor, human epidermal growth factor receptor 2, Ki-67, p53 and Bcl-2) have been studied exhaustively. Ki-67, p53 and Bcl-2 are suggested to be important but weak prognostic markers, by meta-analyses of the results. Cyclin $\mathrm{E}$, vascular endothelial growth factor $A, p 16^{I N K 4 A}, p 27^{k i p 1}$ and $\beta$-catenin are promising candidates, but require further study in large randomised clinical trial samples by using standardised assays and scoring systems. Some issues and inconsistencies in the reported studies to date are highlighted and discussed. A guideline for a multi-phase approach for conducting future studies on prognostic immunohistochemistry markers is proposed here.

See end of article for authors' affiliations

.....................

Correspondence to: Dr M-S Tsao, Department of Pathology, Princess Margaret Hospital, 610 University Avenue, Toronto, Ontario, Canada M5G 2M9;

Ming.tsao@uhn.on.ca

Accepted for publication 4 January 2006 ung cancer is the leading cause of cancer death in North America and throughout the world. In North America, annual deaths from lung cancer are greater than the next three most common cancers combined (breast, prostate and colon). Non-small cell lung carcinoma (NSCLC) accounts for about $80 \%$ of all lung cancers. The current management of NSCLC is largely guided by tumour stage. Patients with early stage (I and II) tumour are treated by surgical resection with or without adjuvant chemotherapy, and stage III patients require combined modality approaches that may include chemotherapy, radiation and surgery. Nevertheless, the overall 5-year survival rates of these patients remain relatively poor, ranging from $70 \%$ for stage IA patients to $25 \%$ for stage IIIA patients whose tumours are surgically resectable. ${ }^{1}$ Most deaths are caused by metastatic recurrence. Differing survival outcomes among patients within a stage suggests the existence of other tumour factors affecting prognosis.

Cancer cells manifest complex genetic aberrations that occur during multi-stage carcinogenesis. Genomic instability or selection leads to aberrations that can be grouped into six essential pathways: the acquisition of (1) self-sufficient or autonomous growth signals; (2) insensitivity to growth-inhibitory signals; (3) resistance to signals of apoptosis; (4) unlimited proliferation potential; (5) sustained angiogenesis; and (6) invasion and metastasis. ${ }^{2}$ Each of these pathways is regulated by further sets of interacting subpathways, which result in redundancy and additional complexities on the roadmap to malignancy. Despite this, some molecular aberrations are more likely than others to influence the clinical behaviour of a cancer, including the risk of metastasis. Such aberrations, once identified, could potentially serve as prognostic markers, which are tumour (or patient) characteristics that may influence and predict the clinical outcome of a cancer patient.

Molecular prognostic markers could potentially be represented by changes in gene copy number, messenger RNA (mRNA) expression or protein expression levels. Immunohistochemistry (IHC) is the most practical method of assessing protein expression changes in histopathology. IHC not only provides a semiquantitative assessment of protein abundance but also defines the cellular localisation of expression. It may also detect functionally important post-translational protein modifications, such as phosphorylation. These

Abbreviations: $A D C$, adenocarcinoma; $C C N$, cyclin; CDK, cyclin-dependent kinase; ECM, extracellular matrix; EGFR, epidermal growth factor receptor; FHIT, fragile histidine triad; HER, human epidermal growth factor receptor; HGF, hepatocyte growth factor; hTERT, human telomerase reverse transcriptase; $I \mathrm{HC}$,

immunohistochemistry; MMP, matrix metalloproteinase; mRNA, messenger RNA; NSCLC, non-small cell lung carcinoma; PCNA, proliferating cell nuclear antigen; SQCC, squamous cell carcinoma; TGF- $\beta$, transforming growth factor $\beta$; TIMP, tissue inhibitors of

metalloproteinase; VEGF, vascular endothelial growth factor 
considerations have led to the extensive use of IHC in studies on prognostic markers for tumours. In this review, we shall summarise to the best of our ability the results of these studies on NSCLC.

\section{MATERIALS AND METHODS}

We searched PubMed with the MeSH terms "non-small cell lung carcinoma" and "immunohistochemistry" and "prognosis", with the search limited to "humans" and "English language". This search produced 462 papers and 12 reviews dating from May 1987 to October 2005. For individual markers, additional and confirmatory searches were carried out with "gene of interest" and "non-small cell lung cancer" and "immunohistochemistry". When the same group of investigators published multiple manuscripts on a marker and used overlapping patient cohorts, only the most recent one or the one directly dealing with its prognostic value was emphasised. If meta-analyses or reviews on a specific marker were published, these were considered in place of the original reports (table 1). To limit the scope of this review, we have discussed in more detail only markers that have figured in four or more independent studies. Reports in journals that are difficult to access were also excluded from detailed review. A summary of results from these studies has been compiled and is available at http://www.uhnres.utoronto.ca/ labs/tsao/ under supplimentary data.

The prognostic significance of a marker is normally evaluated by Cox proportional regression analysis or logrank testing for its association with disease-free or overall survival. Independent prognostic markers are identified by multivariate analysis, which adjusts for other clinical and pathological factors.

\section{RESULTS}

\section{Self-sufficiency for growth pathway}

Cells require mitogenic growth signals to enter into the cell cycle. Neoplastic cells invariably show reduced dependence on such signals. This may result from altered expression of soluble growth factors or their receptors, altered cell-cell or cell-stroma interactions and intrinsic activation of growth signal transducers. ${ }^{2}$ Interactions may be mediated by autocrine, paracrine or endocrine mechanisms. ${ }^{4}$ In an autocrine loop, cells express both the receptor and its ligand(s). Interactions between tumour and host stromal cells exemplify the paracrine interactions, whereas hormones are the prototype of endocrine signalling.

\section{Epidermal growth factor receptor family}

The epidermal growth factor receptor (EGFR)/ErbB family of trans-membrane receptor tyrosine kinases consists of four members: EGFR/human epidermal growth factor receptor-1 (HER-1)/ErbB-1，HER-2/c-neu/ErbB-2，HER-3/ErbB-3 and HER-4/ErbB4. ${ }^{5}$ These proteins share $40-50 \%$ amino-acid homology and have a common domain organisation. On activation by the ligand, these receptors signal through the RAS-RAF-mitogen-activated protein kinase and phosphatidylinositol 3'-kinase pathways, which play critical roles in regulating cell proliferation and survival.

Meert et al ${ }^{6}$ systematically reviewed 16 studies published between 1989 and 2001, of which 14 were based on immunohistochemistry (IHC). The overall EGFR expression rate in NSCLC was $51 \%$. Expression was less frequent in adenocarcinoma (ADC, 46.2\%) than in squamous cell carcinoma (SQCC, 82.6\%). Three quarters of the studies (12/16) did not find EGFR expression to be prognostic. A quantitative meta-analysis of eight evaluable IHC studies showed that EGFR IHC expression was marginally significant as a negative (poor) prognostic marker (table 1). In another review, Nicholson et al covered reports published during 1985-2000, and found that only $20 \%$ and $10 \%$ of studies associated increased EGFR levels with decreased recurrencefree survival and overall survival, respectively. Seven additional studies have since confirmed that EGFR IHC is not a prognostic marker for NSCLC, ${ }^{8-14}$ whereas one study with questionable analytical methods reported a prognostic significance. ${ }^{15}$ Recent, albeit preliminary, evidence, however, suggests that EGFR IHC may yet assume an important role as a predictive marker for response and survival benefit in patients with advanced NSCLC treated by the small-molecule EGFR inhibitors gefitinib and erlotinib. ${ }^{16}{ }^{17}$

A review of 44 reports (39 studies before August 2004) on HER-2 expression in NSCLC showed an overall positive staining rate of $35 \%$, using cut-offs chosen by the various investigators. ${ }^{18}$ HER-2 overexpression differed significantly between histological subtype (38\% in ADC, 16\% in SQCC and $18 \%$ in large cell carcinoma, $\mathrm{p}<0.0001)$. Among 20 studies (including two that used non-IHC assays) with data evaluable for meta-analysis, eight IHC studies reported a significant detrimental effect of HER-2 expression on survival, whereas 10 reported no significant prognostic value. A meta-analysis of these studies suggested that HER-2 overexpression was a relevant poor prognostic marker for 3year and 5-year survivals, especially among patients with ADC (table 1). The authors, however, warned that several minor studies were excluded from the meta-analysis as they failed to meet the eligibility criteria for meta-analysis; thus the results require caution in interpretation. Two additional studies were published after the meta-analysis. A study on tissue microarray of samples from 284 patients reported that HER-2 expression was a significant predictor of poor survival

Table 1 Summary of meta-analyses of the results of studies on candidate immunohistochemistry markers for survival of patients with non-small cell lung carcinoma

\begin{tabular}{|c|c|c|c|c|c|c|c|}
\hline Marker & First author & Published studies & $\begin{array}{l}\text { Number of } \\
\text { eligible studies }\end{array}$ & $\begin{array}{l}\text { Number of } \\
\text { patients }\end{array}$ & $\begin{array}{l}\text { Overall } \\
\mathrm{HR}^{*}\end{array}$ & $95 \% \mathrm{Cl}$ & Significance/comment \\
\hline EGFR & Meert $^{6}$ & Until July 2001 & 8 & 1987 & 1.13 & 1.00 to 1.28 & \multirow{6}{*}{$\begin{array}{l}\text { Weak significance } \\
\text { Not significant } \\
17 / 27 \text { negative studies excluded for } \\
\text { lack of detailed survival data } \\
\text { True significance requires prospective } \\
\text { and multivariate confirmation by a } \\
\text { standardised technique, scoring criteria } \\
\text { and cut-offs }\end{array}$} \\
\hline P21RAS & Mascaux ${ }^{29}$ & Until July 2003 & 7 & 989 & 1.08 & 0.86 to 1.34 & \\
\hline HER-2 & Nakamura $^{18}$ & Until August 2004 & 18 & 2579 & 1.32 & 1.14 to 1.65 & \\
\hline P53 & Steels ${ }^{108}$ & Until July 1999 & $\begin{array}{l}8 \text { (Pab1801) } \\
16 \text { (DO-7) }\end{array}$ & $\begin{array}{l}1035 \\
2067\end{array}$ & $\begin{array}{l}1.57 \\
1.25\end{array}$ & $\begin{array}{l}1.28 \text { to } 1.91 \\
1.09 \text { to } 1.43\end{array}$ & \\
\hline $\mathrm{Ki}-67$ & Martin $^{61}$ & $\begin{array}{l}\text { Until December } \\
2002\end{array}$ & 16 & 1863 & 1.55 & 1.34 to 1.78 & \\
\hline $\mathrm{Bcl}-2$ & Martin $^{129}$ & $\begin{array}{l}1993 \text { to December } \\
1999\end{array}$ & 18 & 2909 & 0.72 & 0.64 to 0.82 & \\
\hline
\end{tabular}

$\mathrm{Cl}$, confidence interval; EGFR, epidermal growth factor receptor; HER, human epidermal growth factor receptor; HR, hazard ratio of death for high expression of the marker.

${ }^{*} \mathrm{HR}>1$ implies worse survival for the group with increased expression of the marker, whereas $\mathrm{HR}<1(\mathrm{Bcl}-2)$ indicates better survival for the group with higher expression. For p53, the prognostic significance of studies that used Pab1801 and DO7 antibodies were separately analysed. 
in patients with lung ADC, but only 2 of 80 patients expressed this protein. ${ }^{19}$ A second study on 345 patients also included a rather extensive comparative analysis of various scoring criteria, but reported no noteworthy association between HER-2 expression and prognosis. ${ }^{20}$ Overall, the prognostic significance of HER-2 has not been established.

\section{Hepatocyte growth factor and Met receptor}

Hepatocyte growth factor (HGF) is also known as scatter factor, a multifunctional cytokine with putative roles in cell proliferation, motility, angiogenesis and morphogenesis. ${ }^{21}$ Met is the tyrosine kinase receptor for $\mathrm{HGF} / \mathrm{scatter}$ factor. The prevalent concept regarding HGF-Met signalling is that it is paracrine, with the Met receptor expressed by epithelial cells and the HGF ligand secreted by stroma fibroblasts. Tsao et al, ${ }^{22}$ however, showed common expression of HGF mRNA and protein in tumour cells, indicating that HGF-Met autocrine signalling also plays an important role in NSCLC. The reported rates of Met expression or overexpression in NSCLC were $40-60 \% .{ }^{23-25}$ Takanami et al ${ }^{25}$ reported that Met expression was an independent poor prognostic marker in ADC. In contrast with other studies that did not find considerable Met expression in tumour stroma cells, ${ }^{24}{ }^{25}$ Tokunou $\mathrm{et} \mathrm{al}^{26}$ found Met stromal overexpression in 53\% of lung $\mathrm{ADC}$, and this staining was associated with shorter survival for the patients. Takanami et $a^{25}$ also reported that tumour expression of HGF in ADC was a poor prognostic marker, but only in univariate analysis. Overall, the prognostic roles of Met and HGF in NSCLC remain uncertain, and additional studies using well-characterised and specific antibodies are warranted.

\section{Growth signal transducers}

RAS is a small G-protein with intrinsic GTPase activity. It is a critical regulator of signalling downstream of cell surface receptors. ${ }^{27}$ Point mutations on codon 12,13 or 61 of the ras family genes result in their oncogenic activation, whose significance in NSCLC has recently been proved by a transgenic mouse model. ${ }^{28}$ Ras mutations are found in approximately $20 \%$ of NSCLC, and they mainly occur in ADC or large-cell carcinoma. The prognostic significance of ras mutation remains indeterminate, but the frequency and significance of RAS protein overexpression in lung cancer has been poorly investigated. A meta-analysis of seven evaluable IHC studies showed the absence of prognostic value for RAS protein expression in NSCLC. ${ }^{29}$ One possible lack of enthusiasm to study RAS protein expression could be the lack of antibodies with confirmed specificity and reactivity for use in IHC.

\section{Cell cycle checkpoint promoters}

Cell cycle includes the G0 (quiescent), Gl (resting), S (DNA synthesis), G2 (pre-mitotic gap) and M (mitotic) phases. Progression between these phases is an orderly process tightly regulated by complex yet redundant mechanisms that include multiple checkpoints, which are used to assess growth signals, cell size and DNA integrity. ${ }^{30}$ Cell cycle progression is promoted by cyclins (CCNs) and CCNdependent kinases (CDKs). The constitutive and persistent high expression of these regulators may cause failure of checkpoint arrests and may lead to uncontrolled proliferation. The CCN family has 18 members (A-I, L and T), each of which may have multiple isoforms (eg, CCNDl-3). The CDKs are also composed of several family members, from CDKl (cdc2) to CDK11. The key CCNs and CDKs are CCNA ( $\mathrm{S}$ and G2 phases), CCNB (G2/M transition), CCND and CCNE (G1/S transition), as well as CDK1 (G2/M transition), CDK2 ( $\mathrm{S}$ phase), CDK4 and CDK6 (Gl/S transition).

CCNDl is the most studied CCN in NSCLC. Among 15 reports reviewed, ${ }^{19}{ }^{31-44}$ CCNDl expression or overexpression was noted in approximately 50\% of NSCLC, but its overall prognostic value remains uncertain. Five studies identified CCNDl overexpression as a negative prognostic marker, ${ }^{32} 33384042$ whereas three others associated it with better prognosis. ${ }^{19} 3537$ Only two poor prognostic reports remained significant in multivariate analyses. ${ }^{38} 42$ The remaining seven reports reported no association. ${ }^{31} 343639414344$

The overexpression of CCNE is also common $(\sim 45 \%)$ in NSCLC. $^{35} 394045-49$ Five of eight studies showed a significant association between CCNE overexpression and worse prognosis, ${ }^{39}{ }^{45-49}$ and three of them found it to be a significant independent marker after adjusting for stage. ${ }^{39} 45$ By using reverse transcription-polymerase chain reaction assay, Muller-Tidow et $a l^{50}$ also reported that CCNE mRNA overexpression was an independent poor prognostic marker in 70 patients with NSCLC.

Proliferating cell nuclear antigen (PCNA) is the subunit of DNA polymerase $\delta$ responsible for its proofreading activity, which has a marked role in maintaining the fidelity of mammalian DNA replication. Thus, overexpression of PCNA may potentially influence cell cycle progression and modulate the effectiveness of radiation and chemotherapy. At least 12 studies have evaluated the prognostic value of PCNA overexpression in NSCLC, ${ }^{42}{ }^{44}$ 51-60 with more studies reporting no prognostic value of PCNA overexpression. Ki-67, another nuclear antigen that is expressed only in proliferating cells, preferentially during the late G1, S, G2 and M phases of the cell cycle, is commonly used as a marker to evaluate proliferation of tumour cells. Almost all studies have used the MIBl antibody to evaluate Ki-67 by IHC. Martin et al ${ }^{61}$ recently conducted a meta-analysis of studies published before 2003 and identified only 15 of 37 studies (41\%) that reported a negative effect of Ki-67 overexpression on prognosis for patients with NSCLC. In all, 16 studies on 1863 patients with NSCLC were evaluable for the metaanalysis. The aggregated survival data showed that Ki-67 immunoreactivity was associated with poorer survival (hazard ratio (HR) 1.55, 95\% confidence interval (CI) 1.34 to 1.78) and the HR remained significant even within histological subtypes. Four of nine additional studies reported since 2002 also reported that Ki-67 expression was associated with a poorer prognosis. ${ }^{848} 62-68$

\section{Insensitivity to growth inhibition pathway}

A balance between stimulators and inhibitors of cell proliferation maintains growth homeostasis in normal cells. Resistance to growth-inhibitory factors is an essential step in carcinogenesis. Inhibitory signals may originate from the tumour cells themselves or from their microenvironment. These factors could be soluble molecules, the actions of which are mediated by autocrine, paracrine or endocrine mechanisms. Transforming growth factor $\beta$ (TGF- $\beta$ ) is generally an antiproliferative factor for epithelial cells and is produced mainly by the stromal cells. Evidence, however, suggests that TGF- $\beta$ may promote tumour progression. ${ }^{69}$ Few studies have explored the prognostic significance of TGF- $\beta$ expression in NSCLC. ${ }^{70-72}$ These studies have provided contradictory results in both the prognostic significance and cellular localisation of TGF- $\beta$ expression. ${ }^{72} 73$

$\mathrm{CCN}$-dependent kinase inhibitors are negative regulators of CCNs and CDKs. ${ }^{74}$ Two major groups exist: the CIP/KIP family genes (p21, p27 and p57), which inhibit all CDKs, and the INK4 family genes (pl6, p15, pl8 and p19) that inhibit CDK4/6. The loss of CCN-dependent kinase inhibitors should theoretically, therefore, lead to restraint on the proliferative stimuli of tumour cells, thereby leading to tumour progression and poorer prognosis. Less than half the studies on the prognostic effect of $221^{\text {wafl/cipl }}$ in NSCLC have reported significant differences, although this may be owing to the 
small sample sizes of the individual studies. ${ }^{19} 41$ 70 75-78 By contrast, seven of nine studies have reported a noticeable adverse survival effect on the loss of p2 $7^{\text {kipl }}$ protein expression in NSCLC. ${ }^{19}{ }^{48}$ N9-85 $^{75}$ Loss of p27 expression has been reported in approximately $30 \%$ of NSCLC. It is worth noting that unlike many proteins whose protein levels are tightly regulated by gene transcription, the protein level of p27 is mainly regulated by post-translational phosphorylation at the threonine 187 site and degradation through the ubiquitin/26S proteasome pathway. ${ }^{86}$ Overall, p27 appears worthy of further evaluation as a potential prognostic marker in clinical trial samples of large cohorts.

The INK4 family proteins bind to CDK4 or CDK6 individually, thereby inhibiting their kinase activities at the mid-Gl phase..$^{87}$ The loss or inactivation of $\mathrm{pl} 6^{I N K 4 A}$ results in unchecked activity of CDK4 that phosphorylates retinoblastoma protein, thus releasing the E2F to exert its transcriptional activity. $\mathrm{P}^{I} 6^{I N K 4 A}$ is inactivated in approximately $50 \%$ (range 25-60) of NSCLC. ${ }^{34} 3841768385$ 88-94 In approximately $30 \%$ of tumours, inactivation is by homozygotic deletion, whereas inactivation by mutation is rare. ${ }^{95-97}$ The others are inactivated mainly by promoter hypermethylation. Among 12 studies that have assessed the clinical effect of p16 protein expression, six reported that retention of pl6 staining in tumour cells was a good prognostic marker, ${ }^{387688} 899293$ although only two of them showed significance in multivariate analysis. ${ }^{76} 93$ Two additional studies found pl6 loss to be a poor prognostic marker, but only in early-stage tumours or SQCC. ${ }^{34}{ }^{90}$ Thus, despite some discordance, pl6 represents a promising marker for further evaluation.

Retinoblastoma protein inactivation may achieve the same results as p16 inactivation and serves as an alternate pathway to promote G1-S cell cycle progression. Loss of retinoblastoma protein expression at variable levels has been reported in approximately $30 \%$ of NSCLC samples, but there is no convincing evidence to suggest that it is a significant prognostic marker. 343841889194 97-104

\section{Resistance to the apoptosis pathway}

Apoptosis is orchestrated by the sequential activation of caspases, a family of cysteine proteases with specificity for aspartic acid residues. Two pathways may mediate apoptosis: (a) the death receptors pathway (tumour necrosis factor, Fas ligand or TRAIL receptors) that activates caspase 8 and 10 and (b) the mitochondrial pathway that activates caspase 9 . Both pathways lead to effector caspases (3, 6 and 7). ${ }^{105} \mathrm{Bcl}-2$ is antiapoptotic for the mitochondria pathway, whereas Bax is a proapoptotic factor activated by $\mathrm{p} 53$.

p53 gene is the most studied gene in all types of cancer, including lung cancer. IHC can detect missense mutant p53 proteins, but may not detect the protein products of nonsense, deletion or truncation mutants. This is partially responsible for the incomplete concordance between p53positive IHC and sequencing results. ${ }^{106}{ }^{107}$ At least three metaanalyses have been carried out on the prognostic value of p53 gene alterations in NSCLC. ${ }^{108-110}$ The frequency of p53 mutation or positive IHC staining is consistently higher in SQCC than in ADC. Although more studies have reported no prognostic significance of p53 IHC than studies that associated it with poor prognosis, the overall conclusion of these meta-analyses is that p53 staining has some adverse prognostic effect in patients with NSCLC (table 1). The strength of this significance, however, remains to be confirmed prospectively and in clinical trials on large patient cohorts with more homogeneous and well-defined patient populations. Since these meta-analyses, more than 20 additional retrospective small cohort studies have been reported. Unfortunately, overall, they provided similarly contradictory results as those reviewed in the metaanalyses. ${ }^{81942606575778593111-119}$

MDM2 is the E3 ubiquitin ligase that targets p53 for nuclear export and degradation. MDM2 and p53 form a feedback loop that is also modulated by $\mathrm{p} 14^{A R F}$, the alternate spliced product of INK4 gene that also produces $\mathrm{pl}^{\text {INK4A }}$. P14 ${ }^{A R F}$ binds MDM2, thus the overexpression of p14 would lead to a sequestration q MDM2 and prevents its binding with p53, thus resulting in stabilisation of the p53 protein. This is the postulated mechanism wherein p53 protein overexpression is found in the absence of mutation. ${ }^{120}$ The precise role of MDM2 in tumour progression, however, remains uncertain. ${ }^{121}$ Although MDM2 gene amplification has been associated with poor prognosis, ${ }^{122}$ MDM2 mRNA expression has also been reported to be a favourable prognostic marker in patients with NSCLC. ${ }^{123}$ Five studies have evaluated the prognostic value of MDM2 IHC in patients with NSCLC. ${ }^{123-127}$ Whereas three studies did not find MDM2 expression to be prognostic, two groups have reported MDM2 staining to be a favourable prognostic marker in p53-negative patients with NSCLC. ${ }^{124} 127$

At least 20 members in the Bcl-2 family share at least one conserved Bcl-2 homology domain. ${ }^{128}$ These are subdivided into prosurvival (antiapoptosis) family members, including $\mathrm{Bcl}-2, \mathrm{Bcl}-\mathrm{x}_{\mathrm{L}}$ and $\mathrm{Bcl}-\mathrm{W}$, and proapoptosis families, including Bax, Bak and Bok. There are also Bcl-2 homology 3-only proteins that promote cell death, including Bid, Bim, Bik, Bad, Bmf, Hrk, Noxa and Puma. The balance between prosurvival and proapoptosis factors determines whether a cell will respond to apoptotic signals. A meta-analysis of publications from 1993 to 1999 examined the prognostic significance of Bcl-2 in lung cancer (table 1). ${ }^{129}$ Among 21 studies on NSCLC, 10 reported Bcl-2 expression as a good prognostic factor, whereas one reported it as a poor prognostic marker. The expression of Bcl-2 was found in approximately $35 \%$ of NSCLC, being more common in ADC $(61 \%)$ than in SQCC $(32 \%)$. Counter-intuitive to the antiapoptotic function of Bcl-2, a meta-analysis of 18 studies with evaluable data and comprising 2909 patients showed a better survival outcome for patients with Bcl-2-positive tumours (HR $0.72,95 \%$ CI 0.64 to 0.82 ). The results were similar for the two antibodies most commonly used (clone 100 or 124) and the four ranges of thresholds used as cut-off (table 1). Since the meta-analysis, there have been 27 additional independent IHC studies, ${ }^{8} 4460103112113117119$ 130-145 most of them using the clone 100 and 124 antibodies. The mean Bcl-2 expression rate (34\%) was remarkably similar to those included in the meta-analyses, and approximately $40 \%$ of the studies reported Bcl-2 expression to be a good prognostic marker.

No prognostic significance seems to exist for Bax in NSCLC. ${ }^{67} 92119130140146-149$ Only one of seven studies indicated an association of Bax expression with better survival, ${ }^{119}$ whereas the others failed to show significance, including one study that evaluated only patients treated by chemotherapy. ${ }^{147}$

\section{Unlimited growth potential pathway}

Telomerase complex, which contains an RNA subunit human telomerase RNA gene (hTERC) and a protein catalytic subunit human telomerase reverse transcriptase (hTERT), is responsible for the maintenance of integrity of chromosomal telomeres and genomic stability. IHC detection of hTERT expression is frequent in NSCLC $(50-90 \%)^{150-152}$ and has been correlated with increased telomerase activity, ${ }^{150}{ }^{152}$ but is not predictive of survival. The specificity and sensitivity of hTERT antibody for IHC has not proved to be optimal. Even with the best available monoclonal antibody 44F12 that gives a single band in western blot, the concordance rates of IHC staining 
and western blot, telomerase activity and mRNA expression as detected by in situ hybridisation were $76 \%, 70 \%$ and $70 \%$, respectively. ${ }^{152}$

\section{Sustained angiogenesis pathway}

Angiogenesis is crucial for primary tumour growth and metastasis, and comprises interactions between tumour cells, endothelial cells and stroma cells. Growth factors and cytokines have been implicated in angiogenesis, as well as proteases that break down extracellular matrix (ECM). Vascular endothelial growth factor (VEGF), also known as vascular permeability factor, is a key regulator of angiogenesis in physiological and pathological conditions. ${ }^{153}$ To date, seven family members of VEGF have been identified, including VEGF-A (also known as VEGF), VEGF-B, VEGFC, VEGF-D, VEGF-E, placenta growth factor 1 and placenta growth factor 2. ${ }^{154}$ Overexpression of VEGF has been associated with tumour progression and poor prognosis in most cancer types, and novel antiangiogenic agents have recently been approved or are in various phases of clinical trials for cancer treatment. ${ }^{155}$ VEGF expression or overexpression has been reported in approximately $60 \%$ of NSCLC. Most studies have indicated a significant positive correlation between VEGF immunoreactivity and tumour vascularity.$^{67}{ }^{156-159}$ To date, seven of 12 studies have reported that higher VEGF protein expression predicts poorer survival for patients with NSCLC, and four of these studies identified it as an independent prognostic marker. ${ }^{67} 150$ 156-158 160-166 Four of five studies have also shown that VEGF-C is a predictor of poor prognosis, but only one found it to be an independent marker. ${ }^{67} 164$ 167-169

\section{Invasion and the metastasis pathway}

Aside from angiogenesis, the breakdown of intercellular junctional complexes and ECM proteins by tumour cells is also an important process in tumour progression. Integrins, cadherins, selectins, the immunoglobulin super gene family (IgSF) and CD44 are families of adhesion or junctional molecules with different genetic and biochemical properties. Factors that alter the abundance or function of ECM proteins and adhesion or junctional molecules may influence the ability of tumour cells to invade and metastasise, and thus cancer prognosis.

E-cadherin and catenins are components of adherens junction protein, with crucial roles in the maintenance of intercellular junctions in epithelial cells. Thus, reduced catenin and E-cadherin expression could potentially affect tumour differentiation, metastasis and prognosis. In all, three family members of catenin exist, $\alpha, \beta$ and $\gamma$. Whereas $\alpha$ catenins and $\gamma$-catenins strictly participate in junctional complex formations, $\beta$-catenin is also associated with the regulation of transcription through the wingless-type MMTV integration site family pathway. ${ }^{170}{ }^{171}$ Expression of catenins has usually been assessed in conjunction with that of their partner protein E-cadherin. Eight studies have evaluated the prognostic role of $\beta$-catenin in NSCLC ${ }^{172-179}$; three of these simultaneously investigated the significance of $\alpha$-catenins and $\gamma$-catenins. ${ }^{172} 176177$ Reduced expression of $\beta$-catenin was found in about $30 \%$ of NSCLC, and five studies reported the association of reduced staining with poor prognosis. ${ }^{172}{ }^{175-178}$ Interestingly, two of three studies that investigated the $\alpha$ catenins and $\gamma$-catenins also found that their reduced expression was a poor prognostic marker. ${ }^{176}{ }^{177}$ Four of seven studies reviewed also reported favourable prognosis for NSCLC tumours that retained normal E-cadherin expression, with two studies remaining significant in multivariate analysis. ${ }^{173}$ 175-177 179-181 Thus, $\beta$-catenin and E-cadherin are worthy candidates for further investigation.

Matrix metalloproteinases (MMPs) comprise of almost 20 family members and are the only enzymes that can degrade fibrillar collagens. There are also four tissue inhibitors of metalloproteinase (TIMPs), which are endogenous anti-MMP molecules. ${ }^{182}$ Although the expression of many of these MMPs and TIMPs has been studied by IHC, most have focused on the gelatinases MMP-2 and MMP-9. ${ }^{163} 166183-188$ Results from most of these studies have suggested that high expressions of MMP-2 and MMP-9 are poor prognostic markers for NSCLC, especially the expression of MMP-2. Most of these studies have identified tumour cell expression of the MMPs as prognostic, ${ }^{163}{ }^{183-185} 187$ whereas Ishikawa et $a l^{186}$ reported that the stroma, but not tumour cell expression of MMP-2, was prognostic. Increasing evidence resulting from in situ hybridisation and laser capture microdissection coupled with real-time reverse transcription-polymerase chain reaction technique suggests that most MMPs and TIMPs are predominantly expressed in the stroma rather than in the tumour cells, ${ }^{189}$ whereas in nearly all published studies the focus has been almost exclusively on tumour cell expression, with few studies reporting on both tumour and stroma cells. Overall, the role of MMP IHC in the prognosis of NSCLC should be studied further, but these need to be accompanied by a very vigorous validation of the specificity of the antibodies.

\section{Other candidate markers}

Our discussion is restricted to markers that have been studied in four or more independent studies. A large number of markers exist, however, which have been less studied but have shown either promising or controversial results as prognostic indicators (fig 1). Markers in which expression changes have been associated with worse prognosis in at least two studies, and which have no reports of an opposite association, are considered to be promising candidate markers. These include CCNA (two studies), ${ }^{49} 59$ CCNBl (two of three studies), ${ }^{168} 190191$ carbonic anhydrase IX (two studies) ${ }^{166} 192$ and fragile histidine triad (FHIT; two of four studies). ${ }^{116}{ }^{193-195}$ In these markers positive expression is associated with poorer prognosis, although retained (positive) FHIT expression is associated with better outcome.

\section{DISCUSSION AND CONCLUSION}

Of 17 markers that have been investigated by eight or more groups (fig 1), none have shown consistent results in all studies. There are, however, six markers (overexpression of CCNE and VEGF-A, and loss of $\mathrm{p} 16^{I N K 4 A}, \mathrm{p} 27^{\text {kipl }}, \beta$-catenin, and E-cadherin) that have shown correlation with poor prognosis in $50 \%$ or more of the studies, without contrary results. Interestingly, markers that have been studied most exhaustively (EGFR, HER-2, Ki-67, p53 and Bcl-2) have all reported inconsistent results, perhaps suggesting that their prognostic values are at best weak. In addition to the above markers, there are other promising markers that have been less studied, yet have shown significant results more often than non-significant results. These may also be worthy of further validation, and include HGF/Met, CCNA, CCNBI, VEGF-C, carbonic anhydrase (CA) IX, $\alpha$-catenin and $\gamma$ catenin, MMP-2, MMP-9 and FHIT.

Our review has largely confirmed what is well known among pathologists and oncologists - that studies on prognostic markers, particularly, but not exclusively, those including immunohistochemical assays, often give rise to inconsistent or contradictory results. The issue has become especially urgent as oncology is entering the dawn of personalised medicine with targeted treatments. ${ }^{196} 197$ Recently, the Statistics Subcommittee of the NCI-EORTC Working Group on Cancer Diagnostics has published the REporting recommendations for tumour MARKer prognostic studies (REMARK) guidelines. ${ }^{198}$ The data we collected during this review (http://www.uhnres.utoronto.ca/labs/ 

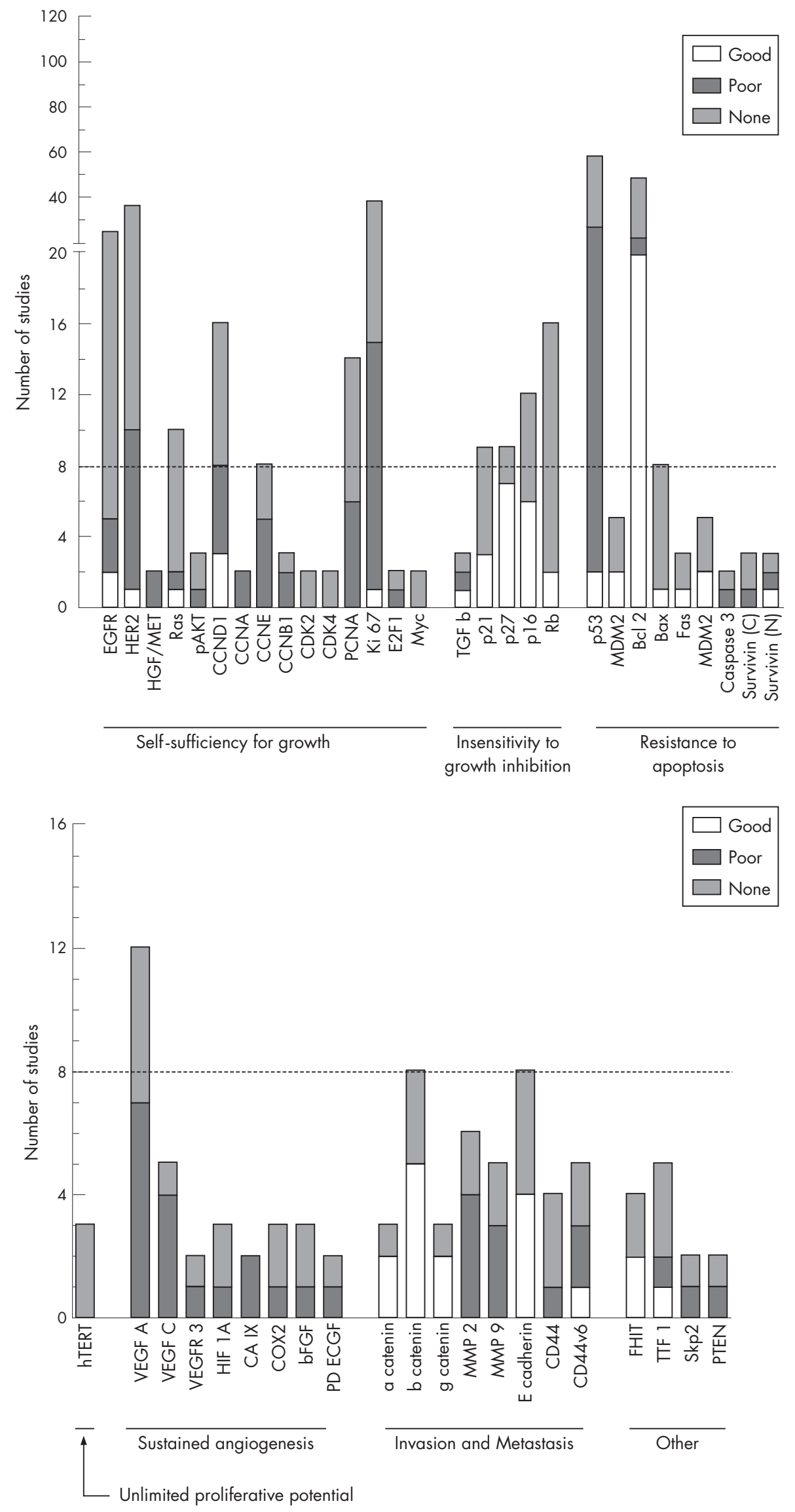

Figure 1 Number of reports for markers that have been studied by two or more independent groups of researchers. For each marker, the graphs also indicate the relative distribution of studies that showed significant association of high expression or overexpression with good (favourable) prognosis, poor prognosis or no prognostic value. The broken line is to facilitate identifying markers that have been studied by eight or more groups. The detailed summaries of markers and their deregulations are available at http://www.uhnres. utoronto.ca/labs/tsao/index.php. 
tsao/supplementary-data.php) clearly highlight the multiple study design factors that have contributed to the inconsistencies and contradictions. Many of these issues require serious discussion by the pathologist community.

For almost all markers, diverse sources and types of antibodies have been used. Multiple antibodies per se should not become an issue as long as each antibody has been well characterised for its specificity and sensitivity. For many markers, especially new ones, the quality assurance for the antibody is often not adequately described. Specification of the method used to determine the antibody titre that is finally adopted is often neglected. Including representative low and high photomicrographs of the staining would also go a long way in convincing readers that the staining is probably specific.

It should be recognised that IHC scoring is at best a semiquantitative exercise for which no standard criteria have as yet been proposed or adopted. The heterogeneity in scoring methods possibly partly reflects our difficulty in coming to grips with genotypic and phenotypic (expression) heterogeneity in tumours. Unfortunately, our understanding of the cause and effect of these heterogeneities, including immunostaining, is almost non-existent, thus making it difficult to design rational and biologically meaningful scoring criteria. The scoring methods that have been used included estimating the grade of staining intensity (numerically from absent to strong), percentage of tumour cells stained, cellular localisation of the antigen and systems that combined these parameters. The approaches to combining the intensity and percentage of cells stained have also been divergent, including a direct multiplication of the percentage of stained cells with staining intensity score, or of grouping the staining percentage into 3-4 scores and then summing this with the intensity score. Although superficially the two methods could lead to comparable final scores, in reality, the former could unreasonably overweight the percentage score. The only scoring system that has been generally accepted is the one used to assess HER-2/c-erbB2 staining. Perhaps a more important confusion that permeates many biomarker corre- lative studies, especially IHC, is the method of determining cut-offs for dichotomising scores in log-rank tests. Cut-offs were often arbitrary and sometimes selected to obtain the desired effect by the "minimum p value" approach. ${ }^{199}$ Such approaches have led to the existence of diverse but poorly justified cut-offs, which may contribute to non-reproducibility of the results. In general, taking the median as cut-offs for log-rank tests provides the most unbiased, albeit stringent, criteria for analysis, but selecting multiple rationally justified cut-offs is also worthy of performing. ${ }^{199}$

Unlike predictive markers for the efficacy of specific treatment, prognostic markers in NSCLC are most relevant for early-stage or resectable tumours. By including patients with advanced-stage tumour into cohorts of patients with primarily early-stage tumour, we may introduce unwanted effects. Some studies have reported that specific markers could have different prognostic significance in patients with early-stage tumours as compared with those with advancedstage tumours, or in different histological subtypes. ${ }^{101}$ Unfortunately, subgroup analysis will reduce the number of patients in each subgroup, and thus may underpower the statistical analysis. Biased selection of patient cohorts may also lead to results that will be difficult to reproduce in other studies.

The most relevant end point for assessing the prognostic value of a marker is its association with overall or diseasefree survival. Correlations with stage or tumour grade may provide insights into the tumour biology, but are weak and inadequate parameters for assessing the significance of the outcome. As marker expression can be correlated with other clinical and pathological parameters (eg, age, stage, sex), which may also influence prognosis, only multivariate analysis that adjusts for these factors is more likely to become clinically useful. Studies with small sample size $(<100$ cases $)$ more often than not will fail such stringent statistical tests. ${ }^{196}$

Last but not least, we have limited our review to the prognostic significance of individual markers, although most of them were published in the context of studies on multiple

Table 2 Proposed multiphase evaluations of immunohistochemical prognostic markers

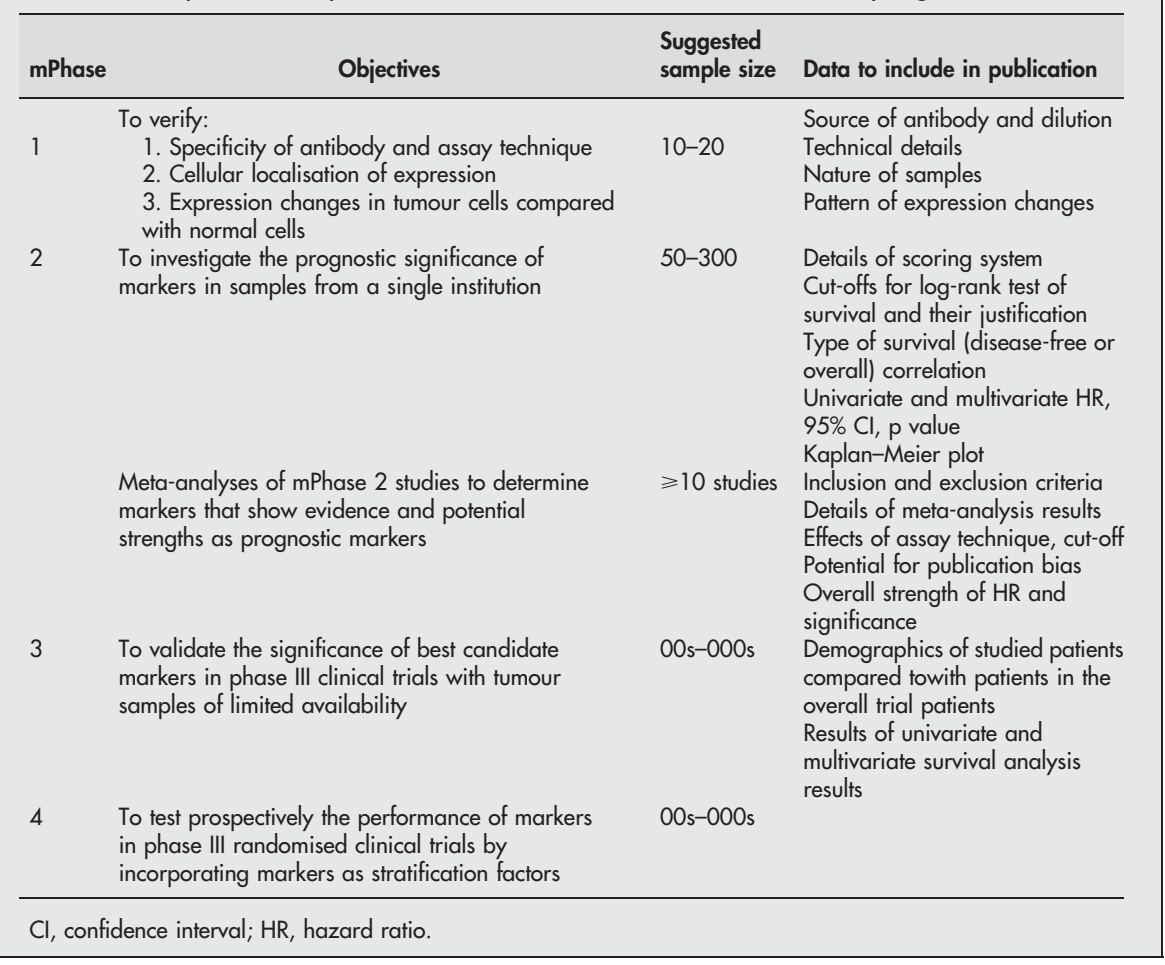


markers. Many of these studies have reported that whereas an individual marker was not prognostic, a combination phenotype could be prognostic, but such analyses could raise many issues and caveats that are beyond the scope of the current review.

In accordance with the above caveats, we suggest that perhaps studies on tumour biomarkers should adopt a similar multi-phase approach as that being used in clinical trials for new therapeutics (table 2). Most studies may combine marker Phase (mPhase) 1 and 2 studies but even in this early stage of marker evaluation, a conceptual multi-phase approach would provide a more consistent reporting of the studies. We believe that all results, including the full data from well-conducted mPhase 1 and 2 studies, should be reported to avoid publication biases. ${ }^{200}$ Meta-analyses on markers for which 10 or more mPhase 2 studies have been reported would provide important insights on whether such markers are worthy of further mPhase 3 studies on samples of patients participating in phase III controlled and randomised clinical trials. These samples are usually of limited availability, and thus should be reserved only for advanced validation of the best candidate markers. The ultimate (mPhase 4) test for the clinical effect of a marker will be when it becomes a stratification factor in prospectively designed phase III clinical trials. A rigorous implementation of such a multi-phase approach to studies on prognostic markers can improve our chances of identifying true prognostic markers that may be reliably applied in our clinical practice.

\section{ACKNOWLEDGEMENTS}

This work is supported by grant 02-MAY-0132 from the Ontario Cancer Research Network and grant \# 015184 from the Canadian Cancer Society and National Cancer Institute of Canada. Dr Tsao is the M Qasim Choksi Chairman in Lung Cancer Translational Research. Dr Ling is supported by a visiting scholarship from the China Scholarship Foundation. We thank Dr Sarit Aviel-Ronen and Dr Frances Shepherd for critical comments and Davina Lau and Daniel Gomez for assistance in data collection.

\section{Authors' affiliations}

C-Q Zhu, W Shih, C-H Ling, M-S Tsao, Department of Pathology, University Health Network, Princess Margaret Hospital, Toronto, Ontario M5G 2C4, Canada

Competing interests: None.

${ }^{*}$ Current address: The First Affiliated Hospital of Soochow University, Suzhou, China

\section{REFERENCES}

1 Mountain CF. The international system for staging lung cancer. Semin Surg Oncol 2000;18:106-15

2 Hanahan D, Weinberg RA. The hallmarks of cancer. Cell 2000;100:57-70.

3 Sieber OM, Heinimann K, Tomlinson IP. Genomic instability-the engine of tumorigenesis? Nat Rev Cancer 2003;3:701-8

4 Sporn MB, Todaro GJ. Autocrine secretion and malignant transformation of cells. N Engl J Med 1980;303:878-80.

5 Mosesson Y, Yarden Y. Oncogenic growth factor receptors: implications for signal transduction therapy. Semin Cancer Biol 2004;14:262-70.

6 Meert AP, Martin B, Delmotte P, et al. The role of EGF-R expression on patient survival in lung cancer: a systematic review with meta-analysis. Eur Respir J 2002;20:975-81.

7 Nicholson RI, Gee JM, Harper ME. EGFR and cancer prognosis. Eur J Cancer 2001;37(Suppl 4):S9-15

8 Hilbe W, Dirnhofer S, Oberwasserlechner F, et al. Immunohistochemical typing of non-small cell lung cancer on cryostat sections: correlation with clinical parameters and prognosis. J Clin Pathol 2003;56:736-41.

9 Hirsch FR, Varella-Garcia M, Bunn PA Jr, et al. Epidermal growth factor receptor in non-small-cell lung carcinomas: correlation between gene copy number and protein expression and impact on prognosis. J Clin Oncol 2003;21:3798-807.

10 Brattstrom D, Wester K, Bergqvist M, et al. HER-2, EGFR, COX-2 expression status correlated to microvessel density and survival in resected non-small cell lung cancer. Acta Oncol 2004;43:80-6.
11 Swinson DE, Cox G, O'Byrne KJ. Coexpression of epidermal growth factor receptor with related factors is associated with a poor prognosis in nonsmall-cell lung cancer. Br J Cancer 2004;91:1301-7

12 Onn A, Correa AM, Gilcrease M, et al. Synchronous overexpression of epidermal growth factor receptor and HER2-neu protein is a predictor of poor outcome in patients with stage I non-small cell lung cancer. Clin Cancer Res 2004; 10:136-43.

13 Hirami Y, Aoe M, Tsukuda K, et al. Relation of epidermal growth factor receptor, phosphorylated-Akt and hypoxia-inducible factor $1-\alpha$ in non-small cell lung cancer. Cancer Lett 2004;214:157-64.

14 Berghmans T, Meert AP, Martin B, et al. Prognostic role of epidermal growth factor receptor in stage III nonsmall cell lung cancer. Eur Respir J 2005;25:329-35

15 Niemiec J, Kolodziejski L, Dyczek S. EGFR LI and Ki-67 LI are independent prognostic parameters influencing survivals of surgically treated squamous cell lung cancer patients. Neoplasma 2005:52:231-7.

16 Cappuzzo F, Hirsch FR, Rossi E, et al. Epidermal growth factor receptor gene and protein and gefitinib sensitivity in non-small-cell lung cancer. J Natl Cancer Inst 2005;97:643-55.

17 Tsao MS, Sakurada A, Cutz JC, et al. Erlotinib in lung cancer - molecular and clinical predictors of outcome. N Engl J Med 2005;353:133-44.

18 Nakamura H, Kawasaki N, Taguchi M, et al. Association of HER-2 overexpression with prognosis in nonsmall cell lung carcinoma: a metaanalysis. Cancer 2005;103:1865-73.

19 Au NH, Cheang M, Huntsman DG, et al. Evaluation of immunohistochemical markers in non-small cell lung cancer by unsupervised hierarchical clustering analysis: a tissue microarray study of 284 cases and 18 markers. J Pathol 2004; 204:101-9.

20 Pelosi G, Del Curto B, Dell'Orto P, et al. Lack of prognostic implications of HER-2/neu abnormalities in 345 stage I non-small cell carcinomas (NSCLC) and 207 stage I-III neuroendocrine tumours (NET) of the lung. Int $J$ Cancer 2005;113:101-8.

21 Birchmeier C, Birchmeier W, Gherardi E, et al. Met, metastasis, motility and more. Nat Rev Mol Cell Biol 2003;4:915-25.

22 Tsao MS, Yang Y, Marcus A, et al. Hepatocyte growth factor is predominantly expressed by the carcinoma cells in non-small-cell lung cancer. Hum Pathol 2001;32:57-65.

23 Masuya D, Huang C, Liu D, et al. The tumour-stromal interaction between intratumoral c-Met and stromal hepatocyte growth factor associated with tumour growth and prognosis in non-small-cell lung cancer patients. Br J Cancer 2004;90:1555-62.

24 Tsao MS, Liu N, Chen JR, et al. Differential expression of Met/hepatocyte growth factor receptor in subtypes of non-small cell lung cancers. Lung Cancer 1998;20:1-16.

25 Takanami I, Tanana F, Hashizume T, et al. Hepatocyte growth factor and cMet/hepatocyte growth factor receptor in pulmonary adenocarcinomas: an evaluation of their expression as prognostic markers. Oncology 1996;53:392-7

26 Tokunou M, Niki T, Eguchi K, et al. c-MET expression in myofibroblasts: role in autocrine activation and prognostic significance in lung adenocarcinoma. Am J Pathol 2001;158:1451-63.

27 Pronk GJ, Bos JL. The role of p21 ras in receptor tyrosine kinase signalling. Biochim Biophys Acta 1994:1198:131-47.

28 Johnson L, Mercer K, Greenbaum D, et al. Somatic activation of the K-ras oncogene causes early onset lung cancer in mice. Nature 2001;410:1111-6.

29 Mascaux C, lannino N, Martin B, et al. The role of RAS oncogene in survival of patients with lung cancer: a systematic review of the literature with metaanalysis. Br J Cancer 2005;92:131-9.

30 Kastan MB, Bartek J. Cell-cycle checkpoints and cancer. Nature 2004:432:316-23.

31 Kwa HB, Michalides RJ, Dijkman JH, et al. The prognostic value of NCAM, p53 and cyclin D1 in resected non-small cell lung cancer. Lung Cancer 1996; 14:207-17

32 Caputi M, Groeger AM, Esposito V, et al. Prognostic role of cyclin D1 in lung cancer: relationship to proliferating cell nuclear antigen. Am J Respir Cell Mol Biol 1999;20:746-50.

33 Keum JS, Kong G, Yang SC, et al. Cyclin D1 overexpression is an indicator of poor prognosis in resectable non-small cell lung cancer. $\mathrm{Br} J$ Cancer 1999:81:127-32.

34 Brambilla E, Moro D, Gazzeri S, et al. Alterations of expression of Rb, p16(INK4A) and cyclin D1 in non-small cell lung carcinoma and their clinical significance. J Pathol 1999;188:351-60.

35 Anton RC, Coffey DM, Gondo MM, et al. The expression of cyclins DI and E in predicting short-term survival in squamous cell carcinoma of the lung. Mod Pathol 2000;13:1167-72.

36 Volm M, Koomagi R. Relevance of proliferative and pro-apoptotic factors in non-small-cell lung cancer for patient survival. Br J Cancer 2000;82:1747-54.

37 Grugger M, Kappeler A, Vonlanthen S, et al. Alterations of cell cycle regulators are less frequent in advanced non-small cell lung cancer than in resectable tumours. Lung Cancer 2001;33:229-39.

38 Jin $\mathrm{M}$, Inoue S, Umemura T, et al. Cyclin D1, pl6 and retinoblastoma gene product expression as a predictor for prognosis in non-small cell lung cancer at stages I and II. Lung Cancer 2001;34:207-18.

39 Dosaka-Akita H, Hommura F, Mishina T, et al. A risk-stratification model of non-small cell lung cancers using cyclin E, Ki-67, and ras p21: different roles of $\mathrm{Gl}$ cyclins in cell proliferation and prognosis. Cancer Res $2001: 61: 2500-4$ 
40 Ikehara $M$, Oshita F, Ito $\mathrm{H}$, et al. Expression of cyclin DI but not of cyclin $\mathrm{E}$ is an indicator of poor prognosis in small adenocarcinomas of the lung. Oncol Rep 2003;10:137-9.

41 Burke L, Flieder DB, Guinee DG, et al. Prognostic implication of molecular and immunohistochemical profiles of $\mathrm{Rb}$ and $\mathrm{p} 53$ cell cycle regulatory pathways in primary non-small cell lung carcinoma. Clin Cancer Res 2005; 11:232-41.

42 Esposito V, Baldi A, De Luca A, et al. Cell cycle related proteins as prognostic parameters in radically resected non-small cell lung cancer. J Clin Pathol 2005;58:734-9

43 Dworakowska D, Jassem E, Jassem J, et al. Prognostic value of cyclin DI overexpression in correlation with pRb and p53 status in non-small cell lung cancer (NSCLC). J Cancer Res Clin Oncol 2005;131:479-85.

44 Nguyen VN, Mirejovsky P, Mirejovsky T, et al. Expression of cyclin D1, Ki-67 and PCNA in non-small cell lung cancer: prognostic significance and comparison with p53 and bcl-2. Acta Histochem 2000;102:323-38.

45 Mishina T, Dosaka-Akita H, Hommura F, et al. Cyclin E expression, a potential prognostic marker for non-small cell lung cancers. Clin Cancer Res 2000;6:11-6.

46 Fukuse T, Hirata T, Naiki H, et al. Prognostic significance of cyclin E overexpression in resected non-small cell lung cancer. Cancer Res 2000:60:242-4

47 Hayashi H, Ogawa N, Ishiwa N, et al. High cyclin E and low p27/Kipl expressions are potentially poor prognostic factors in lung adenocarcinoma patients. Lung Cancer 2001;34:59-65

48 Takahashi S, Kamata Y, Tamo W, et al. Relationship between postoperative recurrence and expression of cyclin $\mathrm{E}, \mathrm{p} 27$, and $\mathrm{Ki}-67$ in non-small cell lung cancer without lymph node metastases. Int J Clin Oncol 2002:7:349-55.

49 Dobashi $Y$, Jiang SX, Shoii M, et al. Diversity in expression and prognostic significance of $\mathrm{Gl} / \mathrm{S}$ cyclins in human primary lung carcinomas. J Pathol 2003:199:208-20.

50 Muller-Tidow C, Metzger R, Kugler K, et al. Cyclin E is the only cyclindependent kinase 2-associated cyclin that predicts metastasis and survival in early stage non-small cell lung cancer. Cancer Res 2001;61:647-53.

51 Ishida T, Kaneko S, Akazawa K, et al. Proliferating cell nuclear antigen expression and argyrophilic nucleolar organizer regions as factors influencing prognosis of surgically treated lung cancer patients. Cancer Res 1993;53:5000-3.

52 Ebina M, Steinberg SM, Mulshine JL, et al. Relationship of p53 overexpression and up-regulation of proliferating cell nuclear antigen with the clinical course of non-small cell lung cancer. Cancer Res 1994; $54: 2496-503$

53 Fontanini G, Macchiarini P, Pepe S, et al. The expression of proliferating cell nuclear antigen in paraffin sections of peripheral, node negative non-small cell lung cancer. Cancer 1992;70:1520-7.

54 Bellotti M, Elsner B, De Lima AP, et al. Neural networks as a prognostic tool for patients with non-small cell carcinoma of the lung. Mod Pathol 1997; 10:1221-7.

55 Hirata T, Fukuse T, Naiki H, et al. Expression of CD44 variant exon 6 in stage I non-small cell carcinoma as a prognostic factor. Cancer Res 1998:58:1108-10.

56 Fu XL, Zhu XZ, Shi DR, et al. Study of prognostic predictors for non-small cell lung cancer. Lung Cancer 1999;23:143-52.

57 Fukuse T, Hirata T, Naiki H, et al. Expression of proliferating cell nuclear antigen and CD44 variant isoforms in the primary and metastatic sites of nonsmall cell lung carcinoma with intrapulmonary metastases. Cancer 1999;86:1174-81.

58 Dworakowska D, Gozdz S, Jassem E, et al. Prognostic relevance of proliferating cell nuclear antigen and p53 expression in non-small cell lung cancer. Lung Cancer 2002:35:35-41.

59 Volm M, Koomagi R, Mattern J, et al. Expression profiles of genes in nonsmall cell lung carcinomas from long term surviving patients. Clin Cancer Res 2002;8:1843-8.

60 Grossi F, Loprevite M, Chiaramondia M, et al. Prognostic significance of Kras, p53, bcl-2, PCNA, CD34 in radically resected non-small cell lung cancers. Eur J Cancer 2003;39:1242-50.

61 Martin B, Paesmans M, Mascaux C, et al. Ki-67 expression and patients survival in lung cancer: systematic review of the literature with meta-analysis. Br J Cancer 2004:91:2108-025.

62 Haga Y, Hiroshima K, lyoda A, et al. Ki-67 expression and prognosis for smokers with resected stage I non-small cell lung cancer. Ann Thorac Surg 2003;75:1727-32, discussion 1732-23

63 Fujita Y, Fuijkane T, Fujiuchi S, et al. The diagnostic and prognostic relevance of human telomerase reverse transcriptase mRNA expression detected in situ in patients with nonsmall cell lung carcinoma. Cancer 2003;98:1008-13.

64 Poleri C, Morero JL, Nieva B, et al. Risk of recurrence in patients with surgically resected stage I non-small cell lung carcinoma: histopathologic and immunohistochemical analysis. Chest 2003;123:1858-67.

65 David O, Jett J, LeBeau H, et al. Phospho-Akt overexpression in non-small cell lung cancer confers significant stage-independent survival disadvantage. Clin Cancer Res 2004; 10:6865-71.

$66 \mathrm{Kim}$ SJ, Rabbani ZN, Vollmer RT, et al. Carbonic anhydrase IX in early-stage non-small cell lung cancer. Clin Cancer Res 2004;10:7925-33.

67 Huang C, Liu D, Masuya D, et al. Clinical application of biological markers for treatments of resectable non-small-cell lung cancers. Br J Cancer 2005;92:1231-9.

68 Gasinska A, Kolodziejski L, Niemiec J, et al. Clinical significance of biological differences between cavitated and solid form of squamous cell lung cancer. Lung Cancer 2005;49:171-9.

69 Akhurst RJ. TGF-beta antagonists: why suppress a tumor suppressor? J Clin Invest 2002;109:1533-6.
70 Bennett WP, el-Deiry WS, Rush WL, et al. p21 waf1/cip1 and transforming growth factor beta 1 protein expression correlate with survival in non-small cell lung cancer. Clin Cancer Res 1998;4:1499-506.

71 Inoue $\mathrm{T}$, Ishida T, Takenoyama $M$, et al. The relationship between the immunodetection of transforming growth factor-beta in lung adenocarcinoma and longer survival rates. Surg Oncol 1995;4:51-7.

72 Takanami I, Tanaka F, Hashizume T, et al. Roles of the transforming growth factor beta 1 and its type I and II receptors in the development of a pulmonary adenocarcinoma: results of an immunohistochemical study. J Surg Oncol 1997;64:262-7.

73 Saji H, Nakamura H, Awut I, et al. Significance of expression of TGF-b in pulmonary metastasis in non-small cell lung cancer tissues. Ann Thorac Cardiovasc Surg 2003:9:295-300.

74 Sherr CJ. Cancer cell cycles. Science 1996;274:1672-7.

75 Shoii T, Tanaka F, Takata T, et al. Clinical significance of p21 expression in non-small-cell lung cancer. J Clin Oncol 2002;20:3865-71.

76 Esposito V, Baldi A, Tonini G, et al. Analysis of cell cycle regulator proteins in non-small cell lung cancer. J Clin Pathol 2004:57:58-63.

77 Kalomenidis I, Orphanidou D, Papamichalis G, et al. Combined expression of p53, Bcl-2, and p21WAF-1 proteins in lung cancer and premalignant lesions: association with clinical characteristics. Lung 2002;179:265-78

78 Dworakowska D, Jassem E, Jassem J, et al. Absence of prognostic significance of p21(WAF1/CIP1) protein expression in non-small cell lung cancer. Acta Oncol 2005;44:75-9.

79 Esposito V, Baldi A, De Luca A, et al. Prognostic role of the cyclin-dependent kinase inhibitor p27 in non-small cell lung cancer. Cancer Res 1997:57:3381-5

80 Yatabe Y, Masuda A, Koshikawa T, et al. p27KIP1 in human lung cancers: differential changes in small cell and non-small cell carcinomas. Cancer Res 1998;58:1042-7.

81 Ishihara S, Minato K, Hoshino H, et al. The cyclin-dependent kinase inhibitor p27 as a prognostic factor in advanced non-small cell lung cancer: its immunohistochemical evaluation using biopsy specimens. Lung Cancer 1999;26:187-94

82 Catzavelos C, Tsao MS, DeBoer G, et al. Reduced expression of the cell cycle inhibitor p27Kipl in non-small cell lung carcinoma: a prognostic factor independent of Ras. Cancer Res 1999:59:684-8.

83 Hommura F, Dosaka-Akita H, Mishina T, et al. Prognostic significance of p27KIP1 protein and ki-67 growth fraction in non-small cell lung cancers. Clin Cancer Res 2000;6:4073-81.

84 Tsukamoto S, Sugio K, Sakada T, et al. Reduced expression of cell-cycle regulator p27(Kipl) correlates with a shortened survival in non-small cell lung cancer. Lung Cancer 2001;34:83-90.

85 Hirabayashi H, Ohta M, Tanaka H, et al. Prognostic significance of p27KIPI expression in resected non-small cell lung cancers: analysis in combination with expressions of p16INK4A, pRB, and p53. J Surg Oncol 2002;81:177-84.

86 Sutterluty H, Chatelain E, Marti A, et al. p45SKP2 promotes p27Kip degradation and induces $S$ phase in quiescent cells. Nat Cell Biol 1999:1:207-14

87 Shapiro Gl, Rollins BJ. pl6INK4A as a human tumor suppressor. Biochim Biophys Acta 1996;1242:165-9.

88 Kratzke RA, Greatens TM, Rubins JB, et al. Rb and pl6INK4a expression in resected non-small cell lung tumors. Cancer Res 1996;56:3415-20.

89 Taga S, Osaki T, Ohgami A, et al. Prognostic value of the immunohistochemical detection of p16INK4 expression in nonsmall cell lung carcinoma. Cancer 1997;80:389-95.

90 Huang $\mathrm{Cl}$, Taki T, Higashiyama $\mathrm{M}$, et al. pl6 protein expression is associated with a poor prognosis in squamous cell carcinoma of the lung. Br J Cancer 2000:82:374-80.

91 Chen JT, Chen YC, Chen CY, et al. Loss of p16 and/or pRb protein expression in NSCLC. An immunohistochemical and prognostic study. Lung Cancer 2001;31:163-70.

92 Gessner C, Liebers U, Kuhn H, et al. BAX and pl6INK4A are independent positive prognostic markers for advanced tumour stage of nonsmall cell lung cancer. Eur Respir J 2002; 19:134-40.

93 Cheng YL, Lee SC, Harn HJ, et al. Prognostic prediction of the immunohistochemical expression of $\mathrm{p} 53$ and p16 in resected non-small cell lung cancer. Eur J Cardiothorac Surg 2003;23:221-8.

94 Hommura F, Dosaka-Akita H, Kinoshita I, et al. Predictive value of expression of $\mathrm{p} 16 \mathrm{INK} 4 \mathrm{~A}$, retinoblastoma and $\mathrm{p} 53$ proteins for the prognosis of non-small-cell lung cancers. Br J Cancer 1999;81:696-701.

95 Liggett Jr WH, Sidransky D. Role of the pl6 tumor suppressor gene in cancer. J Clin Oncol 1998:16:1197-206.

96 Kraunz KS, Nelson HH, Lemos M, et al. Homozygous deletion of p16INK4a and tobacco carcinogen exposure in nonsmall cell lung cancer. Int $J$ Cancer 2006; 118:1364-9.

97 Higashiyama M, Doi O, Kodama K, et al. Retinoblastoma protein expression in lung cancer: an immunohistochemical analysis. Oncology 1994;51:544-51

98 Xu HJ, Quinlan DC, Davidson AG, et al. Altered retinoblastoma protein expression and prognosis in early stage non-small cell lung carcinoma. J Natl Cancer Inst 1994:86:695-9.

$99 \mathrm{Kwa} \mathrm{HB}$, Verheijen MG, Litvinov SV, et al. Prognostic factors in resected nonsmall cell lung cancer: an immunohistochemical study of 39 cases. Lung Cancer 1996;16:35-45.

100 Dosaka-Akita H, Hu S-X, Fujino M, et al. Altered retinoblastoma protein expression in nonsmall cell lung cancer. Cancer 1997;79:1329-37.

101 Gugger M, Kappeler A, Vonlanthen S, et al. Alterations of cell cycle regulators are less frequent in advanced non-small cell lung cancer than in resectable tumours. Lung Cancer 2001;33:229-39. 
102 Sugio K, Tsukamoto S, Ushijima C, et al. Clinical significance of the Rb expression in adenocarcinoma of lung. Anticancer Res 2001;21:1931-6.

103 Rigau V, Molina TJ, Chaffaud C, et al. Blood vessel invasion in resected nonsmall cell lung carcinomas is predictive of metastatic occurrence. Lung Cancer 2002;38:169-76.

104 Dworakowska D, Jassem E, Jassem J, et al. Prognostic relevance of altered $\mathrm{pRb}$ and p53 protein expression in surgically treated non-small cell lung cancer patients. Oncology 2004:67:60-6.

105 Igney FH, Krammer PH. Death and anti-death: tumor resistance to apoptosis. Nat Rev Cancer 2002;2:277-88.

106 Carbone DP, Mitsudomi T, Chiba l, et al. p53 immunostaining positivity is associated with reduced survival and is imperfectly correlated with gene mutations in resected non-small cell lung cancer. A preliminary report of LCSG 871. Chest 1994; 106:377S-381S.

107 Tomizawa Y, Kohno T, Fujita T, et al. Correlation between the status of the p53 gene and survival in patients with stage I non-small cell lung carcinoma. Oncogene 1999:18:1007-14.

108 Steels E, Paesmans M, Berghmans T, et al. Role of p53 as a prognostic factor for survival in lung cancer: a systematic review of the literature with a metaanalysis. Eur Respir J 2001;18:705-19.

109 Mitsudomi T, Hamajima N, Ogawa M, et al. Prognostic significance of p53 alterations in patients with non-small cell lung cancer: a meta-analysis. Clin Cancer Res 2000;6:4055-63.

110 Tammemagi MC, McLaughlin JR, Bull SB. Meta-analyses of p53 tumor suppressor gene alterations and clinicopathological features in resected lung cancers. Cancer Epidemiol Biomarkers Prev 1999:8:625-34.

111 Volm M, Koomagi R, Mattern J, et al. Expression profile of genes in nonsmall cell lung carcinomas from long-term surviving patients. Clin Cancer Res 2002;8:1843-8

112 Bubb RS, Komaki R, Hachiya T, et al. Association of Ki-67, p53, and Bcl-2 expression of the primary non-small cell lung cancer lesion with brain metastatic lesion. Int J Radiat Oncol Biol Phys 2002;53:1216-24.

113 Lai R-S, Wang J-S, Hsu H-K, et al. Prognostic evaluation of the expression of p53 and bcl-2 oncoproteins in patients with surgically resected non-small cell ung cancer. Jpn J Clin Oncol 2002;32:393-7.

114 Gajra A, Tatum AH, Newman N, et al. The predictive value of neuroendocrine markers and $\mathrm{p} 53$ for response to chemotherapy and survival in patients with advanced non-small cell lung cancer. Lung Cancer 2002;36:159-65.

115 Han H, Landreneau RJ, Santucci T, ef al. Prognostic value of immunohistochemical expression of p53, HER-2/neu, and bcl-2 in stage I non-small cell lung cancer. Hum Pathol 2002;33:105-10.

116 Chang Y-L, Wu C-T, Shih J-Y, et al. Roles of Fhit and p53 in Taiwanese surgically treated non-small-cell lung cancers. Br J Cancer 2003;89:320-6.

117 Tomita M, Matsuzaki Y, Edagawa M, et al. Prognostic significance of bcl-2 expression in resected pN2 non-small cell lung cancer. EJSO 2003;29:654-7.

118 Tanaka F, Yanagihara K, Otake Y, et al. Prognostic factors in resected pathologic ( $\mathrm{p}-$ ) stage IIIA-N2, non-small cell lung cancer. Ann Surg Oncol 2004; 11:612-8.

119 Groeger AM, Esposito V, De Luca A, et al. Prognostic value of immunohistochemical expression of $\mathrm{p} 53, \mathrm{bax}, \mathrm{Bcl}-2$ and $\mathrm{Bcl}-\mathrm{XL}$ in resected non-small cell lung cancers. Histopathology 2004;44:54-63.

120 Midgley CA, Lane DP. p53 protein stability in tumor cells is not determined by mutation but is dependent on Mdm2 binding. Oncogene 1997; 15:1179-89.

121 Deb SP. Cell cycle regulatory functions of human oncoprotein MDM2. Mol Cancer Res 2003;1:1009-16.

122 Dworakowska D, Jassem E, Jassem J, et al. MDM2 gene amplification: a new independent factor of adverse prognosis in non-small cell lung cancer (NSCLC). Lung Cancer 2004;43:285-95.

123 Ko J-L, Cheng Y-W, Chang S-L, et al. MDM2 mRNA expression is a favorable prognostic factor in non-small cell lung cancer. Int J Cancer 2000;89:265-70.

124 Higashiyama M, Doi O, Kodama K, et al. MDM2 gene amplification and expression in non-small-cell lung cancer: immunohistochemical expression of its protein is a favourable prognostic marker in patients without p53 protein accumulation. Br J Cancer 1997;75:1302-8.

125 Gorgoulis VG, Zacharatos P, Kotsinas A, et al. Alterations of the pl6-pRb pathway and the chromosome locus 9p21-22 in non-small-cell lung carcinomas: relationship with $\mathrm{p} 53$ and MDM2 protein expression. Am J Pathol 1998; 153:1749-65.

126 Dworakowska D, Jassem E, Jassem J, et al. Clinical significance of apoptotic index in non-small cell lung cancer: correlation with $\mathrm{p} 53, \mathrm{mdm} 2, \mathrm{pRb}$ and p21wafl/cipl protein expression. J Cancer Res Clin Oncol 2005; 131:617-23.

127 Wang Y-C, Lin R-K, Tan Y-H, et al. Wild-type p53 overexpression and its correlation with MDM2 and p14ARF alteration: an alternative pathway to non-small cell lung cancer. J Clin Oncol 2005;23:154-64.

128 Cory S, Huang DCS, Adams JM. The Bcl-2 family: roles in cell survival and oncogenesis. Oncogene 2003;22:8590-607.

129 Martin B, Paesmans M, Berghmans T, et al. Role of Bcl-2 as a prognostic factor for survival in lung cancer: a systematic review of the literature with meta-analysis. Br J Cancer 2003;89:55-64.

130 Borner MM, Brousset P, Pfanner-Meyer B, et al. Expression of apoptosis regulatory proteins of the $\mathrm{Bcl}-2$ family and $\mathrm{p} 53$ in primary resected nonsmall-cell lung cancer. Br J Cancer 1999:79:952-8.

131 van de Vaart PJ, Belderbos J, de Jong D, et al. DNA-adduct levels as a predictor of outcome for NSCLC patients receiving daily cisplatin and radiotherapy. Int J Cancer 2000;89:160-6.
132 Cagini L, Monacelli M, Giustozzi G, et al. Biological prognostic factors for early stage completely resected non-small cell lung cancer. J Surg Oncol 2000;74:53-60.

133 Moldvay J, Scheid P, Wild P, et al. Predictive survival markers in patients with surgically resected non-small cell lung carcinoma. Clin Cancer Res 2000;6:1125-34.

134 Kawaguchi T, Yamamoto S, Naka N, et al. Immunohistochemical analysis of $\mathrm{Bcl}-2$ protein in early squamous cell carcinoma of the bronchus treated with photodynamic therapy. Br J Cancer 2000;82:418-23.

135 Cox G, Louise Jones J, Andi A, et al. $\mathrm{Bcl}-2$ is an independent prognostic factor and adds to a biological model for predicting outcome in operable non-small cell lung cancer. Lung Cancer 2001;34:417-26.

136 Kakolyris S, Giatromanolaki A, Koukourakis M, et al. Thioredoxin expression is associated with lymph node status and prognosis in early operable non-small cell lung cancer. Clin Cancer Res 2001;7:3087-91

137 Ferreira CG, van der Valk P, Span SW, et al. Expression of X-linked inhibitor of apoptosis as a novel prognostic marker in radically resected non-small cell lung cancer patients. Clin Cancer Res 2001;7:2468-74.

138 Hwang JH, Lim SC, Kim YC, et al. Apoptosis and bcl-2 expression as predictors of survival in radiation-treated non-small-cell lung cancer. Int J Radiat Oncol Biol Phys 2001;50:13-8.

139 Tanaka F, Otake Y, Yanagihara K, et al. Apoptosis and p53 status predict the efficacy of postoperative administration of UFT in non-small cell lung cancer. Br J Cancer 2001;84:263-9.

140 Hanaoka T, Nakayama J, Haniuda M, et al. Immunohistochemical demonstration of apoptosis-regulated proteins, $\mathrm{Bcl}-2$ and $\mathrm{Bax}$, in resected non-small-cell lung cancers. Int J Clin Oncol 2002;7:152-8.

141 Mattern J, Koomagi R, Volm M. Characteristics of long-term survivors of untreated lung cancer. Lung Cancer 2002;36:277-82.

142 Ludovini V, Gregorc V, Pistola L, et al. Vascular endothelial growth factor, $\mathrm{p} 53, \mathrm{Rb}, \mathrm{Bcl}-2$ expression and response to chemotherapy in advanced nonsmall cell lung cancer. Lung Cancer 2004;46:77-85.

143 Harada T, Ogura S, Yamazaki K, et al. Predictive value of expression of $\mathrm{p} 53, \mathrm{Bcl}-2$ and lung resistance-related protein for response to chemotherapy in non-small cell lung cancer. Cancer Sci 2003;94:394-9.

144 Poleri C, Morero JL, Nieva B, et al. Risk of recurrence in patients with surgically resected stage I non-small cell lung carcinoma. Chest 2003; 123:1858-67.

145 Kren L, Brazdil J, Hermanova M, et al. Prognostic significance of antiapoptosis proteins survivin and bcl-2 in non-small cell lung carcinomas: a clinicopathologic study of 102 cases. Appl Immunohistochem Mol Morphol 2004; 12:44-9.

146 Apolinario RM, van der Valk P, de Jong JS, et al. Prognostic value of the expression of $\mathrm{p} 53, \mathrm{bcl}-2$, and bax oncoproteins, and neovascularization in patients with radically resected non-small-cell lung cancer. J Clin Oncol 1997; 15:2456-66.

147 Krug L, Miller VA, Filippa DA, et al. Bcl-2 and bax expression in advanced non-small cell lung cancer: lack of correlation with chemotherapy response and survival in patients treated with docetaxel plus vinorelbine. Lung Cancer 2003;39:139-43.

148 Koukourakis MI, Giatromanolaki A, O'Byrne KJ, et al. bcl-2 and c-erbB-2 proteins are involved in the regulation of VEGF and of thymidine phosphorylase angiogenic activity in non-small-cell lung cancer. Clin Exp Metastasis 1999; 17:545-54.

149 Huang $C$, Kohno N, Inufusa $H$, et al. Overexpression of bax associated with mutations in the loop-sheet-helix motif of p53. Am J Pathol 1999:155:955-65.

150 Toomey D, Smyth G, Condron C, et al. Immune function, telomerase, and angiogenesis in patients with primary, operable nonsmall cell lung carcinoma: tumor size and lymph node status remain the most important prognostic features. Cancer 2001;92:2648-57.

151 Kumaki F, Kawai T, Hiroi S, et al. Telomerase activity and expression of human telomerase RNA component and human telomerase reverse transcriptase in lung carcinomas. Hum Pathol 2001;32:188-95.

152 Lantuejoul S, Soria JC, Moro-Sibilot D, et al. Differential expression of telomerase reverse transcriptase (hTERT) in lung tumours. Br J Cancer 2004; 90 : 1222-9.

153 Ferrara N, Gerber HP, LeCouter J. The biology of VEGF and its receptors. Nat Med 2003;9:669-76.

154 Hicklin DJ, Ellis LM. Role of the vascular endothelial growth factor pathway in tumor growth and angiogenesis. J Clin Oncol 2005;23:1011-27.

155 Gridelli C. Targeted therapies in the treatment of non small cell lung cancer: reality and hopes. Curr Opin Oncol 2004;16:126-9.

156 Han H, Silverman JF, Santucci TS, et al. Vascular endothelial growth factor expression in stage I non-small cell lung cancer correlates with neoangiogenesis and a poor prognosis. Ann Surg Oncol 2001;8:72-9.

157 Yuan A, Yu CJ, Chen WJ, et al. Correlation of total VEGF mRNA and protein expression with histologic type, tumor angiogenesis, patient survival and timing of relapse in non-small-cell lung cancer. Int $J$ Cancer 2000;89:475-83

158 Inoshima N, Nakanishi Y, Minami T, et al. The influence of dendritic cell infiltration and vascular endothelial growth factor expression on the prognosis of non-small cell lung cancer. Clin Cancer Res 2002;8:3480-6.

159 Tsao MS, Liu N, Nicklee T, et al. Angiogenesis correlates with vascular endothelial growth factor expression but not with $\mathrm{K}$-ras oncogenes activation in non-small cell lung carcinoma. Clin Cancer Res 1997;10:1807-14.

160 O'Byrne KJ, Koukourakis MI, Giatromanolaki A, et al. Vascular endothelial growth factor, platelet-derived endothelial cell growth factor and angiogenesis in non-small-cell lung cancer. Br J Cancer 2000;82:1427-32. 
161 Liao $M$, Wang $\mathrm{H}$, Lin $\mathrm{Z}$, et al. Vascular endothelial growth factor and other biological predictors related to the postoperative survival rate on non-small cell lung cancer. Lung Cancer 2001;33:125-32.

162 Baillie R, Carlile J, Pendleton N, et al. Prognostic value of vascularity and vascular endothelial growth factor expression in non-small cell lung cancer. J Clin Pathol 2001;54:116-20.

163 Shou Y, Hirano T, Gong Y, et al. Influence of angiogenetic factors and matrix metalloproteinases upon tumour progression in non-small-cell lung cancer. Br J Cancer 2001;85:1706-12.

164 Nakashima T, Huang CL, Liu D, et al. Expression of vascular endothelial growth factor-A and vascular endothelial growth factor- $C$ as prognostic factors for non-small cell lung cancer. Med Sci Monitor 2004; 10:BR157-65.

165 Tomita M, Matsuzaki Y, Shimizu T, et al. Vascular endothelial growth factor expression in pN2 non-small cell lung cancer: lack of prognostic value. Respirology 2005; 10:31-5

166 Kim SJ, Rabbani Z, Dewhirst MW, et al. Expression of HIF-1a, CAIX, VEGF, and MMP-9 in surgically resected non-small cell lung cancer. Lung Cancer 2005:49:325-35.

167 Kajita T, Ohta Y, Kimura K, et al. The expression of vascular endothelial growth factor $\mathrm{C}$ and its receptors in non-small cell lung cancer. $\mathrm{Br} J$ Cancer 2001;85:255-60

168 Arinaga M, Noguchi T, Takeno S, et al. Clinical significance of vascular endothelial growth factor $C$ and vascular endothelial growth factor receptor 3 in patients with nonsmall cell lung carcinoma. Cancer 2003;97:457-64.

169 Ogawa E, Takenaka K, Yanagihara K, et al. Clinical significance of VEGF-C status in tumour cells and stromal macrophages in non-small cell lung cancer patients. Br J Cancer 2004;91:498-503.

170 Kobielak A, Fuch E. a-catenin: At the junction of intercellular adhesion and actin dynamics. Nat Rev Mol Cell Biol 2004;5:614-25.

171 Birchmeier W. Cell adhesions and signal transduction in cancer. EMBO Rep 2005;6:413-7.

172 Retera JMAM, Leers MPG, Sulzer MA, et al. The expression of $\beta$-catenin in non-small cell lung cancer: a clinicopathological study. J Clin Pathol 1998;51:891-4.

173 Ramasami S, Kerr KM, Chapman AD, et al. Expression of CD44v6 but not Ecadherin or b-catenin influences prognosis in primary pulmonary adenocarcinoma. J Pathol 2000;192:427-32.

174 Pirinen RT, Hirvikoski P, Johansson RT, et al. Reduced expression of $\alpha$ catenin, $\beta$-catenin, and $\gamma$-catenin is associated with high cell proliferative activity and poor differentiation in non-small cell lung cancer. J Clin Pathol 2001; 54:391-5.

175 Kase S, Sugio K, Yamazaki K, et al. Expression of E-cadherin and betacatenin in human non-small cell lung cancer and the clinical significance. Clin Cancer Res 2000;6:4789-96.

176 Lee YC, Wu CT, Chen CS, et al. The significance of E-cadherin and $\alpha-, \beta-$, and $\gamma$-catenin expression in surgically treated non-small cell lung cancers of $3 \mathrm{~cm}$ or less in size. J Thorac Cardiovasc Surg 2002;123:502-7.

177 Bremnes RM, Veve R, Gabrielson E, et al. High-throughput tissue microarray analysis used to evaluate biology and prognostic significance of the E-cadherin pathway in non-small-cell lung cancer. J Clin Oncol 2002;20:2417-28.

178 Hommura F, Furuuchi K, Yamazaki K, et al. Increased expression of $\beta$ catenin predicts better prognosis in nonsmall cell lung carcinomas. Cancer 2002;94:752-8

179 Choi YS, Shim YM, Kim SH, et al. Prognostic significance of E-cadherin and b-catenin in resected stage I non-small cell lung cancer. Eur J Cardio-thorac Surg 2003;24:441-9.

180 Liu D, Huang CL, Kameyama K, et al. E-cadherin expression associated with differentiation and prognosis in patients with non-small cell lung cancer. Ann Thorac Surg $2001 ; 71: 949-55$.
181 Salzer MA, Leers MPG, van Noord JA, et al. Reduced E-cadherin expression is associated with increased lymph node metastasis and unfavorable prognosis in non-small cell lung cancer. Am J Respir Crit Care Med 1998:157:1319-23.

182 Overall CM, Lopez-Otin C. Strategies for MMP inhibition in cancer: innovations for the post-trial era. Nat Rev Cancer 2002;2:658-72.

183 Passlick B, Sienel W, Seen-Hibler R, et al. Overexpression of matrix metalloproteinase 2 predicts unfavorable outcome in early-stage non-small cell lung cancer. Clin Cancer Res 2000;6:3944-8.

184 Cox G, Jones JL, Andi A, et al. A biological staging model for operable nonsmall cell lung cancer. Thorax 2001;56:561-6.

185 Yamamura T, Nakanishi K, Hiroi S, et al. Expression of membrane-type-1matrix metalloproteinase and metalloproteinase-2 in nonsmall cell lung carcinomas. Lung Cancer 2002;35:249-55.

186 Ishikawa S, Takenaka K, Yanagihara K, et al. Matrix metalloproteinase-2 status in stromal fibroblasts, not in tumor cells, is a significant prognostic factor in non-small-cell lung cancer. Clin Cancer Res 2004; 10:6579-85.

187 Lin TS, Chiou SH, Wang LS, et al. Expression spectra of matrix metalloproteinases in metastatic non-small cell lung cancer. Oncol Rep 2004; 12:717-23.

188 Sienel W, Hellers J, Morresi-Hauf A, et al. Prognostic impact of matrix metalloproteinase-9 in operable non-small cell lung cancer. Int $J$ Cancer 2003; 103:647-51

189 Pedersen TX, Pennington CJ, Almholt K, et al. Extracellular protease mRNA are predominantly expressed in the stromal areas of microdissected mouse breast carcinomas. Carcinogenesis 2005;26:1233-40,

190 Soria JC, Jang J, Khuri FR, et al. Overexpression of cyclin B1 in early stage non-small cell lung cancer and its clinical implication. Cancer Res 2000;60:4000-4.

191 Yoshida T, Tanaka S, Mogi A, et al. The clinical significance of cyclin B1 and Wee 1 expression in non-small cell lung cancer. Ann Oncol 2004; 15:252-6.

192 Swinson DEB, Jones JL, Cox G, et al. Hypoxia-inducible factor-la in non small cell lung cancer: relation to growth factor, protease and apoptosis pathways. Int J Cancer 2004;111:43-50.

193 Tomizawa Y, Nakajima T, Kohno T, et al. Clinicopathological significance of Fhit protein expression in stage I non-small cell lung carcinoma. Cancer Res 1998;58:5478-83.

194 Geradts J, Fong KM, Zimmerman PV, et al. Loss of Fhit expression in nonsmall cell lung cancer: correlation with molecular genetic abnormalities and clinicopathological features. Br J Cancer 2000;82:1191-7.

195 Toledo G, Sola JJ, Lozano MD, et al. Loss of FHIT protein expression is related to high proliferation, low apoptosis and worse prognosis in nonsmall-cell lung cancer. Mod Pathol 2004;17:440-8

196 McShane LM, Altman DG, Sauerbrei W. Identification of clinically useful cancer prognostic factors: what are we missing? J Natl Cancer Inst 2005;97:1023-5.

197 Schilsky RL, Taube SE. Introduction: tumor markers as clinical cancer tests Are we there yet? Semin Oncol 2002;29:211-2.

198 McShane LM, Altman DG, Saverbrei W, et al. REporting recommendations for tumour MARKer prognostic studies (REMARK). Br J Cancer 2005;93:387-91.

199 Altman DG, Lausen B, Sauerbrei W, et al. Dangers of using "optimal" cutpoints in the evaluation of prognostic factors. J Natl Cancer Inst 1994:86:829-35.

200 Kyzas PA, Loizou KT, loannidis JP. Selective reporting biases in cancer prognostic factor studies. J Natl Cancer Inst 2005;97:1043-55. 